\title{
Metals bioremediation potential using Pseudokirchneriella subcapitata
} Potencial de biorremediação de metais pela microalga Pseudokirchneriella subcapitata

\author{
Mônica Ansilago ${ }^{1}$ (), Franciéli Ottonelli ${ }^{1}$ (1), Emerson Machado de Carvalho ${ }^{2}$ (1)
}

\begin{abstract}
A B S T RAC T
Microalgae are unicellular organisms, photosynthesizers that present cell duplication exponentially and biosorption capacity of nutrients dissolved in water. The objective of this work was to evaluate the capacity of the microalga Pseudokirchneriella subcapitata for bioremediation of metals and salts. In this aspect, the reduction of the metals and salts in the synthetic effluents by the microalga $P$. subcapitata was evaluated: (T1) culture medium (control); (T2) culture medium contaminated with aluminum chloride; (T3) culture medium contaminated with ferrous sulfate; (T4) culture medium contaminated with zinc sulfate; (T5) culture medium contaminated with the combination of aluminum chloride, ferrous sulfate and zinc sulfate. The bioremediation process was evaluated by comparing culture media with suspended microalgae to a filtrate version of the same medium. Iron and zinc metals, as well as nitrogen and phosphorus salts, showed depleted values in the filtered medium, indicating efficiency in the treatment of water by microalgae. Aluminum content was below the limit of detection in all treatments. The cumulative values in the microalgae biomass were, in descending order: nitrogen, zinc, iron and phosphorus, thus indicating the assimilation of the contaminants in the algal biomass. In addition, high biomass production of the microalgae was observed. The highest production rate was verified in the synthetic effluent with the association of metals, indicating a synergy between contaminants, which was probably responsible for reducing the toxic effect on the microalgae. These results indicated high potential for bioremediation by microalga $P$. subcapitata, besides the possibility of using algal biomass for biotechnological applications.
\end{abstract}

Keywords: adsorption; biosorption; Chlorophyceae; contaminants.

\section{RE S U M 0}

As microalgas são organismos unicelulares, fotossintetizadores, que apresentam duplicação celular exponencial e capacidade de biossorção de nutrientes dissolvidos na água. $\mathrm{O}$ objetivo deste trabalho foi avaliar a capacidade de biorremediação de metais e sais pela microalga Pseudokirchneriella subcapitata. Nesse aspecto, avaliou-se a redução de metais e sais nos efluentes sintéticos pelas microalgas $P$. subcapitata: (T1) meio de cultura (controle); (T2) meio de cultura contaminado com cloreto de alumínio; (T3) meio de cultura contaminado com sulfato ferroso; (T4) meio de cultura contaminado com sulfato de zinco; (T5) meio de cultura contaminado com a combinação de cloreto de alumínio, sulfato ferroso e sulfato de zinco. O processo de biorremediação foi avaliado comparando o meio de cultura com microalgas em suspensão e o mesmo meio filtrado. Metais de ferro e zinco, assim como sais de nitrogênio e fósforo, apresentaram valores esgotados no meio filtrado, indicando eficiência no tratamento da água por microalgas. O teor de alumínio ficou abaixo do limite de detecção em todos os tratamentos. Os valores acumulados na biomassa de microalgas, em ordem decrescente, foram nitrogênio, zinco, ferro e fósforo, indicando assim a assimilação dos contaminantes na biomassa de algas. Além disso, foi observada alta produção de biomassa das microalgas. A maior taxa de produção foi verificada no efluente sintético com a associação de metais, indicando sinergia entre contaminantes, provavelmente responsável pela redução do efeito tóxico nas microalgas. Esses resultados indicaram alto potencial de biorremediação pela microalga $P$. subcapitata, além da possibilidade de utilização de biomassa de microalgas para aplicações biotecnológicas.

Palavras-chave: adsorção; biossorção; Chlorophyceae; contaminantes.

\footnotetext{
${ }^{1}$ Universidade Federal da Grande Dourados - Dourados (MS), Brazil.

${ }^{2}$ Universidade Federal do Sul da Bahia - Itabuna (BA), Brazil.
}

Received on: 06/12/2020. Accepted on: 10/20/2020

Correspondence address: Mônica Ansilago. Itahum Highway, s/n, CEP: 79804-970, Dourados (MS), Brazil - E-mail: monica_ansilago@hotmail.com. Conflicts of interest: the authors declare that there are no conflicts of interest.

Funding: Fundação de Apoio ao Desenvolvimento do Ensino, Ciência e Tecnologia (FUNDECT).

Received on: 06/12/2020. Accepted on: 10/20/2020

https://doi.org/10.5327/Z21769478834

This is an open access article distributed under the terms of the Creative Commons license. 


\section{Introduction}

Population growth and the development of new production technologies generate continuous environmental impacts. In this scenario, there is a possibility of increasing concentration of contaminants in wastewater, which would require adequate treatment for these effluents (Mahapatra et al., 2014), with the goal of reducing environmental impacts. These contaminants may present a wide variety of organic and inorganic materials, including toxic metals that pose high risks to aquatic environments (Carvalho et al., 2012; Zhang et al., 2016).

In order to reduce the amount of contaminants in wastewater, conventional measures have been adopted, but these are often unsustainable from an environmental, economic and energetic point of view. Thus, there is great interest in the use of microorganisms/ biological materials in effluent treatment processes, due to economic feasibility and low risk to the environment. The use of microorganisms in bioremediation processes is considered a clean and sustainable technology. In addition, this technique makes it possible to recycle nutrients efficiently and add value to the biomass produced (Ramachandra et al., 2013).

Microalgae have high applicability in the field of biotechnology, due to the high rate of biomass production and higher growth tendency (two to ten times) in relation to terrestrial plants. Consequently, the ability of these organisms to absorb solar energy increases the fixation of $\mathrm{CO}_{2}$ by their metabolism (Priyadarshani and Rath, 2012; Sathasivam et al., 2019), and it can increase the production of carbohydrates, proteins, amino acids, lipids and other compounds of interest in algal biomass. Data from the literature suggests high efficiency in the use of microalgae for the reduction of contaminants resulting to effluent treatment. It is possible to observe representative values in the removal of mineral salts (Leong et al., 2018; Mohammadi et al., 2018; Ridley et al., 2018; Saavedra et al., 2018), metals (Peng et al., 2017; Saavedra et al., 2018; Shen et al., 2018), pesticides (González et al., 2012), pharmaceutical compounds (Escapa et al., 2017), oils (Ammar et al., 2018), among others.

Microalgae have been noted for producing lipids (Abdelaziz et al., 2014), proteins, carbohydrates, pigments and carotenoids ( $\beta$-carotene, lutein, chlorophyll, etc.), vitamins (A, B1, B6, folic acid, etc.), antioxidants (catalases, polyphenols, etc.) and other interesting molecules. These bioactive compounds are essential inputs for the food, pharmaceutical and cosmetic industries. In addition, they are an energy source (Priyadarshani and Rath, 2012) and present high market value due to the low costs of the production process. In this strategy, it is possible to use the organism for production of bioactive compounds and surfactants, for different uses in biofuels, biofertilizers, biopolymers, biofilms, among many others (Carvalho et al., 2012; Schmitz et al., 2012; Gouveia et al., 2016).

Some factors are important to regulate the kinetics growth of microalgae and contribute with high production of algal biomass; for instance, the concentration of nutrients present in the medium, the luminosity and the temperature (Carvalho et al., 2012; Wang et al., 2014; Ansilago et al., 2016). Currently, one of the major obstacles in the production of industrial scale microalgae lies in the high cost of culture medium. An alternative culture medium that has been widely used is chemical fertilizer based in nitrogen, phosphorus and potassium (NPK), due to the high concentrations of micro and macronutrients. Besides, it presents low cost, availability in the market and facility in the preparation of culture medium (Sipaúba-Tavares et al., 2009; Carvalho et al., 2012; Ansilago et al., 2016). In order for it to become even more economically attractive, it is necessary to add value to the cultivation process.

Different species of microalgae were used in wastewater treatment processes. Leong et al. (2018) obtained results of removal of up to $98 \%$ of nitrogen in domestic effluent using the microalga Chlorella vulgaris. Saavedra et al. (2018) tested the removal of metals in effluent, obtaining efficiency in manganese (99.4\%), arsenic (40.7\%), barium (38.6\%), zinc (91.90) and copper (88\%) removal, using the microalgae C. vulgaris, Scendesmus almeriensis and Chlorophyceae spp. The microalga C. vulgaris was also used for mercury bioremediation, obtaining removal values of 62.85 and $94.74 \%$ (Peng et al., 2017).

The species Pseudokirchneriella subcapitata has been reported in nutrient removal studies concerning elements such as nitrogen and phosphorus (Gonçalves et al., 2016), as well as in toxicity studies on media containing toxic metals (Gao et al., 2016; Sousa et al., 2018). It is a half moon-shaped, single-celled green algae, with a single chloroplast containing chlorophyll $a$ and $b$ (Granados et al., 2008). This microalga has been used in biotechnological trials to evaluate its tolerance and production under conditions of contamination by toxic metals (Lima, 2010; Carvalho et al., 2012). The data obtained is indicative of the potential of $P$. subcapitata in the complementary treatment of domestic or industrial wastewater.

Although the microalga $P$. subcapitata presents desirable characteristics for wastewater bioremediation, experiments in controlled environments are still needed to evaluate its ability to remove nutrients of water, whether salts and/or metals, as well as to evaluate the production of algal biomass in liquid media substrates with the presence of contaminants. For this purpose, the objective of this study was to evaluate the bioremediation capacity of metals and salts by P. subcapitata microalgae in laboratory culture.

\section{Materials and Methods}

The P. subcapitata inoculum was obtained from the Laboratory of Algae Physiology at Universidade Federal de São Carlos (UFSCar), isolated from the Broa Dam (São Carlos, SP, Brazil). The microalga was cultured and maintained in standard medium $\mathrm{CHU}_{12}$ (Chu, 1942) in the laboratory of the Center for Biodiversity Research (CPBio) at Universidade Estadual de Mato Grosso do Sul 
(UEMS/Dourados, MS, Brazil). The cultivation system was static nonaxenic, with constant aeration and room temperature $(22 \pm$ $2.0^{\circ} \mathrm{C}$ ). The tests were maintained in a BOD incubator with photoperiod control of 2,500 LUX provided by white fluorescent lamps (12 h light/ 12 h dark).

The culture medium of the microalgae was prepared by adding 1 $\mathrm{mL}$ of NPK stock solution to 1 liter of distilled water that was autoclaved at $120^{\circ} \mathrm{C}$ for 20 minutes (e.g., Ansilago et al., 2016). The NPK stock solution was prepared with $0.70 \mathrm{gL}^{-1}$ of chemical fertilizer $\mathrm{N}: \mathrm{P}: \mathrm{K}$ (20-5-20 $\left.\mathrm{gL}^{-1}\right)$, according to Sipaúba-Tavares and Rocha (1993) and Carvalho et al. (2012). The rates of daily growth were obtained by Equation 1:

$$
\left(\mathrm{N}_{\mathrm{n}}-\mathrm{N}_{1}\right) / T
$$

\section{Where:}

$\mathrm{N}_{\mathrm{n}}$ = the algal density value at the desired sample time (number of microalgae cells);

$\mathrm{N}_{1}$ = the algal density value at the initial time of the experiment (number of microalgae cells);

$T=$ the desired sample time (days).

The elaboration of each treatment is described in Table 1. Treatments were performed in triplicate. The value used from each contaminant was established based on the limit allowed by CONAMA's Resolution $n^{\circ}$ 357/2005 (Brasil, 2005), which was doubled.

For the metal analysis, $100 \mathrm{~mL}$ was collected from each Erlenmeyer flask at the beginning of the test (day 1) and at the end of the test (day 21). On day 1, the sample was collected before insertion of P. subcapitata. On the last day of the test, the samples were divided into two equal fractions: one filtered (Whatman microfiber filter, chemically inert, with porosity of $0.45 \mu \mathrm{M}$ ) and another unfiltered (Figure 1), in order to get the Percentage of nutrient removal (\% R) between suspension medium and filtered medium on day 21.

The analysis of metals (zinc, aluminum and iron) was determined by flame atomic absorption spectrometry techniques, EAA-flame, ac- cording to Welz and Sperling (1999). The total phosphorus analyzes were read by visible ultraviolet spectroscopy, UV-VIS, according to Soares et al. (2001). For the total nitrogen analyses, the Kjeldhal microdistillation technique was used, as described in Mantovani et al. (2005), and then titrated by sodium hydroxide $(\mathrm{NaOH})$; subsequently, the value consumed was converted to $\mathrm{mg} \mathrm{L}^{-1}$ of mineral nitrogen, according to Tedesco et al. (1995).

To evaluate the potential bioremediation in each treatment, the concentration values of each nutrient $\left(\mathrm{mg} \mathrm{L}^{-1}\right)$ were compared in the microalgae suspension samples and in the filtered samples. For this, the percentage of removal was used through Equation 2:

$$
\% R=\frac{C_{0}-C_{e}}{C_{0}}(100)
$$

Where:

$\mathrm{C}_{0}$ and $\mathrm{C}_{\mathrm{e}}=$ the concentrations of nutrients in the liquid phase (mg $\mathrm{L}^{-1}$ ) on the $21^{\text {st }}$ day, when microalgae reach the stationary phase of growth, in the suspended material and in the filtrate one, respectively. The data was evaluated via analysis of variance (ANOVA) and Tukey's test, in the statistical program GENES, version DOS and Visual Basic 5.0.

The chemical soil analysis manual of the Paraná Agronomic Institute (Pavan et al., 1992) was used as methodology for the analyses. The laboratory analyses were performed in the Laboratory of Environmental and Instrumental Chemistry at Universidade Estadual do Oeste do Paraná (Unioeste), Marechal Cândido Rondon, PR, Brazil.

\section{Results and Discussion}

To evaluate the bioremediation potential of the P. subcapitata microalgae, the capacities of production in the contaminated medium and removal of contaminants were considered.

The daily growth rate of $P$. subcapitata indicated that the treatment contaminated with aluminum, iron and zinc simultaneously (T5) showed the best algal biomass doubling rate. In addition to the control, this treatment was significantly superior to the other treat-

Table 1 - Composition of treatments used to evaluate microalgae bioremediation by $P$. subcapitata.

\begin{tabular}{|c|c|c|c|c|c|c|}
\hline \multirow{2}{*}{ Treatments } & Adw & NPK & MPs & \multicolumn{3}{|c|}{ Contaminants } \\
\cline { 3 - 6 } & & & $\mathrm{AlCl}_{3}$ & FeSO $_{4}$ & ZnSO $_{4}$ \\
\hline T1 & 400 & 50 & 50 & - & - \\
\hline T2 & 400 & 50 & 50 & 0.32 & - \\
\hline T3 & 400 & 50 & 50 & - & - \\
\hline T4 & 400 & 50 & 50 & - & - \\
\hline T5 & 400 & 50 & 50 & 0.32 & 0.6 \\
\hline
\end{tabular}

Adw: autoclaved distilled water (mL); NPK: cultivation medium with nitrogen, phosphorus and potassium 20-5-20 g L ${ }^{-1}$, respectively (mL); MPs: inoculum with the microalgae $P$. subcapitata $(\mathrm{mL})$; contaminants: synthetic effluent based on aluminum chloride $\left(\mathrm{AlCl}_{3}\right)$, iron sulphate $\left(\mathrm{FeSO}_{4}\right)$ and zinc sulphate $\left(\mathrm{ZnSO}_{4}\right)\left(\mathrm{g} \mathrm{L}^{-1}\right)$. 
ments in the final period of the experiment ( $21^{\text {st }}$ day of experiment). Treatments contaminated only with aluminum (T2), iron (T3) or zinc (T5) showed significantly lower growth rates than control over almost the entire experimental period (Table 2).

Table 2 also shows the analyses resulting from growth curves of P. subcapitata. The analysis of the algal growth curves by the covariance analysis indicated that there was no significant difference between the control and the treatment contaminated with aluminum, iron and zinc simultaneously (T5), corroborating the observations mentioned above. The exponential growth rate $(\mathrm{K})$ indicated better productivity for treatment contaminated simultaneously with the metals and for control, while treatment with zinc contamination presented poor performance. The specific growth rate ( $\mu$ max) also indicated satisfactory production values for control and treatment contaminated with metals simultaneously, as well as treatment contaminated only with iron (T3).
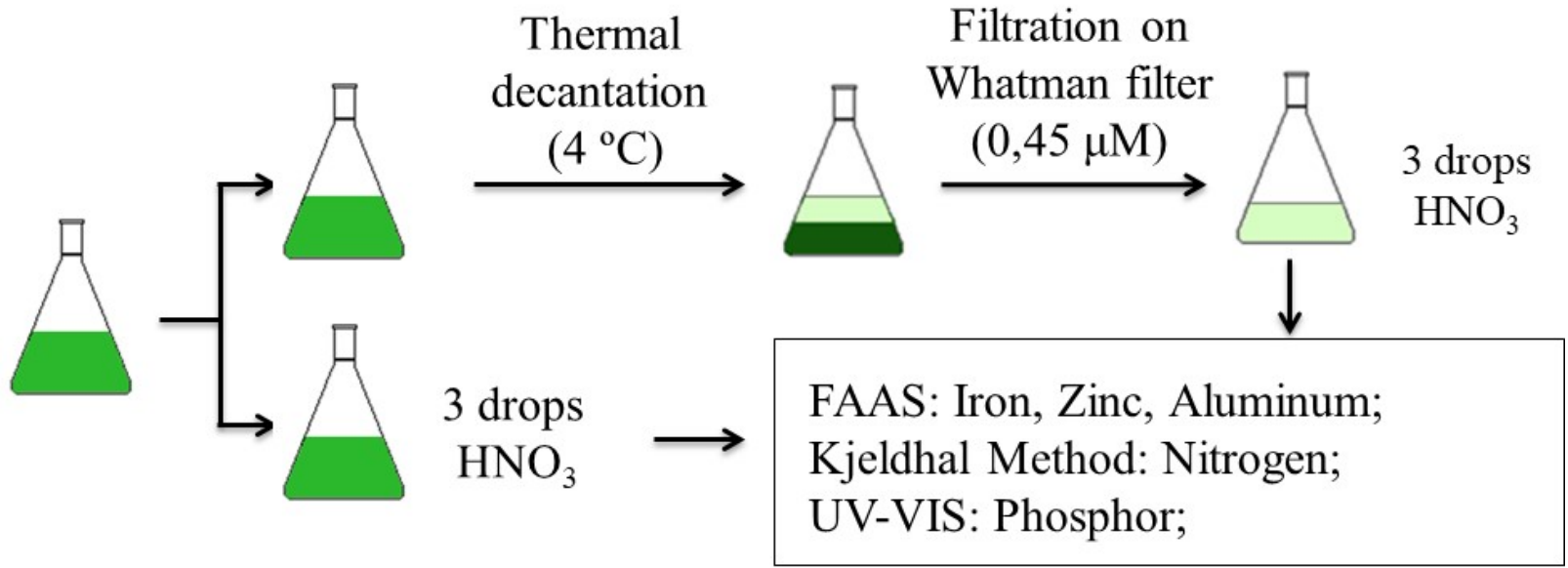

Figure 1 - Schematization of the methodology used for analysis of metals and salts present in microalgae in suspension and filtered culture medium. FAAS: Flame Atomic Absorption Spectrometry; UV-VIS: ultraviolet-visible spectrophotometry.

Table 2 - Analysis of variance (ANOVA) of the daily growth rate of P. subcapitata microalgae (mean \pm standard error) of (T1) culture medium (control); (T2) culture medium contaminated with aluminum chloride; (T3) culture medium contaminated with ferrous sulfate; (T4) culture medium contaminated with zinc sulfate; (T5) culture medium contaminated with the combination of aluminum chloride, ferrous sulfate and zinc sulfate, in each sampling period, followed by analysis of covariance (Ancova), exponential growth rate ( $k$ ) and specific maximum growth $(\mu \max )$ of the 21 days of experiment ${ }^{\star}$.

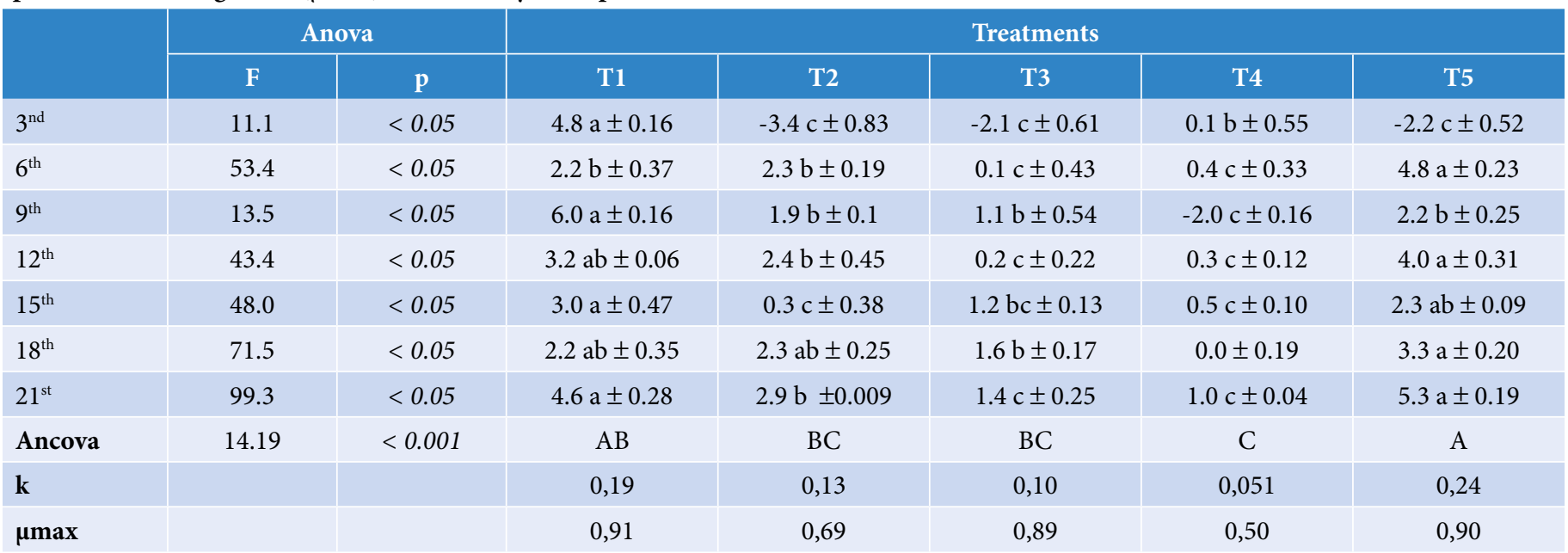

*Analysis of variance at $95 \%$ confidence followed by Tukey's test, represented by lowercase letters in comparison in the lines, where equal letters indicate statistically equal means and different letters have statistically different means between them. Analysis of covariance in the algal growth curve at $99 \%$ reliability, where upper case letters indicate statistically equal means, and different letters have statistically different means between them. 
It was verified, however, that the growth curves of the algal biomass have an exponential behavior only for the medium without contaminant (control) and for the medium contaminated with all the metals simultaneously. It has been observed that all trace elements, even those with biological function, such as zinc, when in higher concentrations, can cause toxicity to organisms. On the other hand, the treatment contaminated with aluminum, iron and zinc (T5) presented the best production, superior even to the control one. In this case, it is possible to observe an antagonistic dynamic, in which the effect of zinc on the exposure of other chemicals, such as iron and aluminum, resulted in the reduction of its toxic effect to microalgae, bringing about effects different from those expected for the action of contaminants alone, which result from synergistic, potentiation, antagonistic and additive interactions (Mozeto and Zagato, 2008).

Another important factor to be analysed in the production of microalgae and in the process of contaminant bioremediation is the monitoring of the $\mathrm{pH}$ of the culture medium. It is observed in Figure 2 that zinc and iron contamination raised the $\mathrm{pH}$ of the culture medium. However, a $\mathrm{pH}$ buffering in the culture medium is observed on the $3^{\text {rd }}$ day of experiment. It is possible to verify the extent to which microalgae absorbed nutrients from the medium, carried out chemical reactions and excreted residues, tending to alter its acid-base balance, which can be verified by $\mathrm{pH}$ fluctuation. Carvalho et al. (2012) observed that the microalga P. subcapitata had considerable growth in an acidic medium, even playing a role in capping the medium.
The increase in density of the algal biomass increases the fixation of $\mathrm{CO}_{2}$ through photosynthesis, providing greater dissociation of carbonate $\left(\mathrm{CO}_{2}^{-2}\right)$ and bicarbonates $\left(\mathrm{HCO}_{2}^{-}\right)$ions, which induces the removal of carbonic acid, and may even precipitate metals in the form of carbonates, followed by the release of $\mathrm{OH}^{-}$ions for the neutralization of the medium (Mota and Von Sperling, 2009; Gardner et al., 2011). All these chemical reactions may explain the increase and subsequent stabilization of $\mathrm{pH}$ in all treatments.

Table 3 presents the percentage of removal of metals and salts during the process of biomass production of the microalgae $P$.

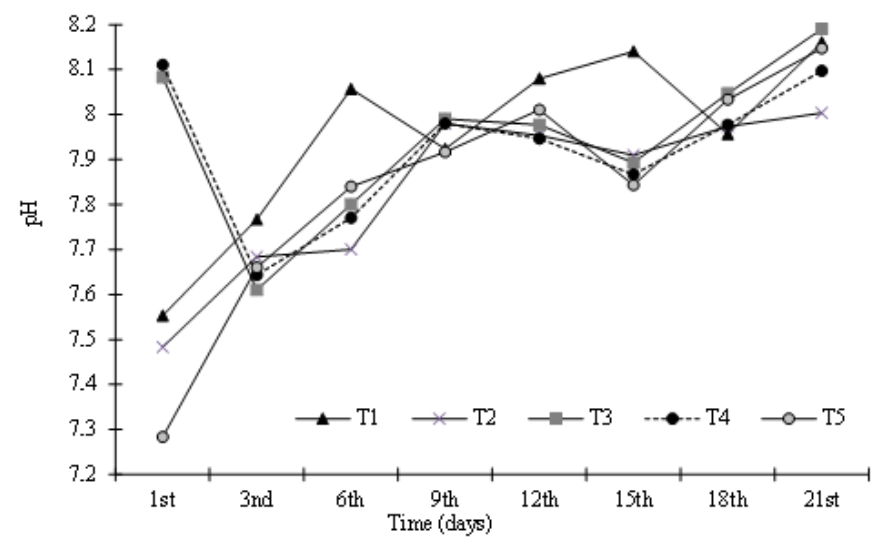

Figure 2 - Ionic potential of hydrogen in culture media used for the production of $P$. subcapitata.

Table 3 - Percentage of nutrient removal (\% R) between suspension medium and filtered medium on day 21 of experiment (mean \pm standard error).

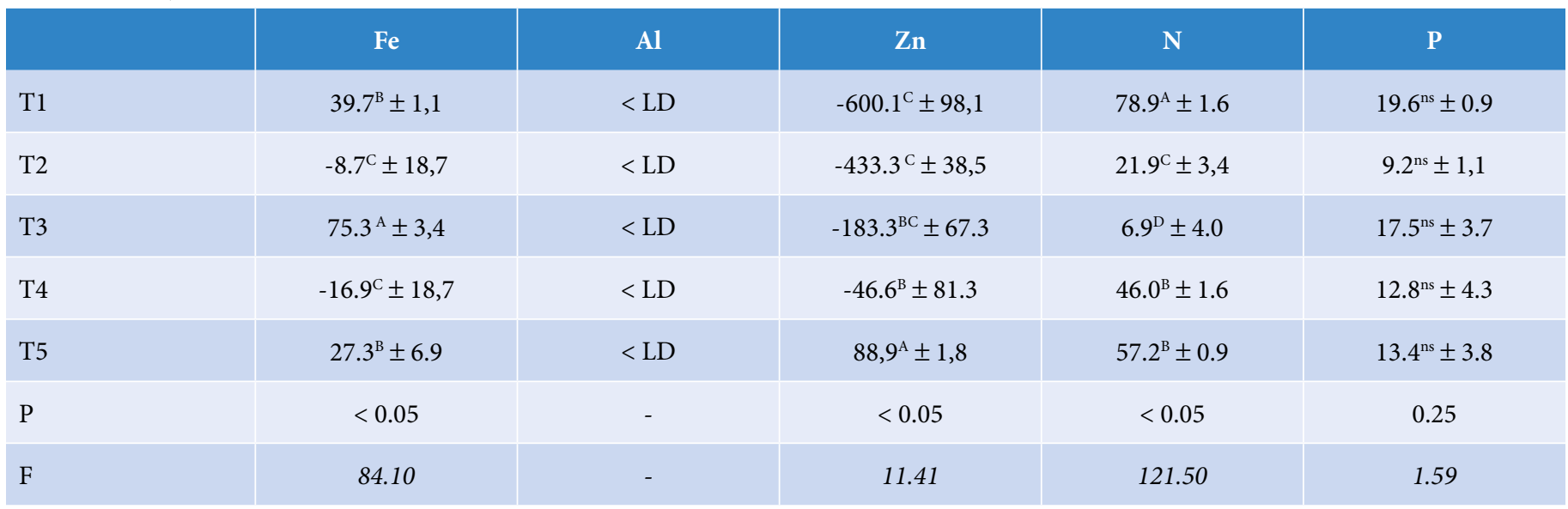

T1: control - no contaminants; T2: treatment contaminated with aluminum; T3: treatment contaminated with iron; T4: treatment contaminated with zinc; T5: treatment contaminated with aluminum + iron + zinc; < LD: elements that have an absorbance value below the detection limit. The analysis of variance $(\mathrm{p}<0.05)$ was performed, followed by Tukey's test in comparison with the lines, where the same letters indicate statistically equal means and different letters present statistically different means. 
subcapitata adsorbed or (bio)sorbed by microalgae. In the analysis of the iron content in the culture medium, values of removal were significantly higher in treatment contaminated with iron (T3), followed by control (T1) and treatment contaminated by all metals simultaneously (T5). Thus, it is possible to infer that the microalgae is able to adsorb or (bio)sorb iron from the medium, even in high concentrations. The capture of metal ions involves some biosorption mechanisms, which are based on ion exchange, coordination, complexation, adsorption and chemical precipitation (Silva et al., 2013).

The results of the aluminum analysis in the medium were below the limit of detection in all treatments, rendering the biore-

Table 4 - Compilation of studies in bioremediation using different microalgae.

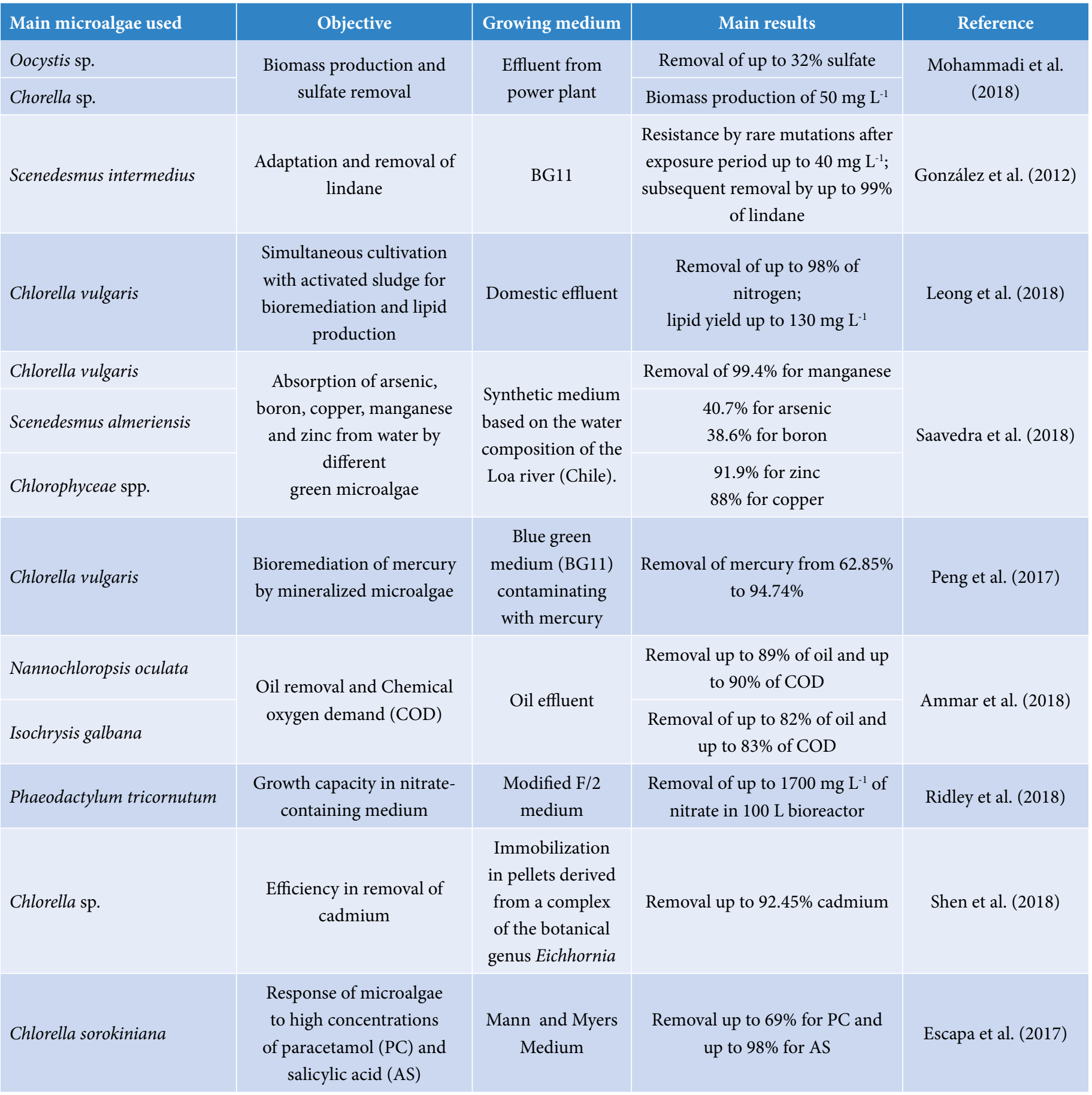


mediation process inconclusive. However, it is possible that aluminum is able to associate with other elements present, making the reading by the method adopted inefficient.

The percentage of zinc removal was effective only in the treatment contaminated with all metals (T5), which showed a reduction of almost $90 \%$. Other treatments, including treatment contaminated with only zinc (T4), had negative removal values. Gao et al. (2016) observed, in their study with P. subcaptata, an elevation of zinc, without toxic potential, in the microalgae with greater exposure to phosphorus, due to potentially induced by $\mathrm{Zn}-\mathrm{P}$ complexation or precipitation inside the cell. Saavedra et al. (2018) also observed removal of up to $91.9 \%$ for zinc in a study carried out with microalgae of the class Chlorophyceae. Other studies indicate that dead algae biomass may be even more efficient at retaining and accumulating metal elements than living cells and tissues (e.g., Cossich, 2000). This process occurs due to the changes in the nature of the cell surface because of the absence of active transport of the dead microalgae, causing better adsorption of metals efficiency by the algal biomass.

The removal of nitrogen in the culture medium was significantly higher in the control (T1). The value of phosphorus removal was also higher in the control, but it did not differ significantly from the previous treatments. It was possible to observe that, in treatments contaminated with metals, the biosorption or adsorption of salts of nitrogen and phosphorus was low. The maximum reduction value recorded was $78.9 \%$ for nitrogen and $19.6 \%$ for phosphorus, all in the control treatment. This fact may have resulted from the Redfield ratio $\left(\mathrm{C}_{106} \mathrm{H}_{118} \mathrm{O}_{45} \mathrm{~N}_{16} \mathrm{P}\right)$, which means that algae, on average, demand 16 times more nitrogen than phosphorus (Redfield, 1958; Sperling, 2001). In a study by Wang et al. (2014), a reduction of up to $95 \%$ and $95.7 \%$ for phosphorus and nitrogen, respectively, was observed in a wastewater treatment system using the microalgae genera Chlorella and Micractinium.

Based on the results, it is possible to observe a complex relationship between microalgae bioremediation processes and the antagonistic and synergistic effects of the contaminants, with each other and with the microalgae itself. However, it is important to establish standards of control and monitoring for these contaminants in the effluent, so that it is possible to understand the metabolism and the efficiency of this system. In Table 4, we present a compilation of studies using different species of microalgae for the specific purpose of culturing, adaptation and bioremediation in media containing metals and other organic and inorganic compounds that can be biosorbed. Through these studies, it can be established that wherever there was insertion and/or presence of stressors in the culture medium of the microalgae, positive results were obtained for the removal of these contaminants and consequent increase in the production of algal biomass. This corroborates the results obtained in the present study, since the treatment contaminated with all metals (iron, aluminum and zinc) (T5) obtained a higher rate of algal biomass duplication, which can indicate synergy between the contaminants, thus reducing the toxic effects.

\section{Conclusion}

The experimental results showed that the microalga $P$. subcapitata presented bioremediation capacity (either by adsorption and/or biosorption) and algal biomass production. The contaminants with higher concentration indices in the culture medium obtained a higher percentage of removal $(\mathrm{N}>\mathrm{Zn}>\mathrm{Fe}>\mathrm{P}>\mathrm{Al})$. It was also possible to observe that, on a bench scale, the microalgae were able to develop in the presence of the toxic metals inserted in the medium.

In addition, the highest production rate was verified in the synthetic effluent with the association of metals, indicating possible synergy between aluminum, iron and zinc, which was probably responsible for reducing the toxic effect on the microalgae, meaning biomass gain for further biotechnological applications.

However, more detailed studies are needed to improve the technique and the methodology used, requiring shorter test times and the use of other contaminating metals for influence and toxicity analysis.

\section{Acknowledgments}

We appreciate the support of Universidade Federal da Grande Dourados - UFGD. Likewise, we thank the Center for Research of Biodiversity at Universidade Estadual de Mato Grosso do Sul for allowing us to use their laboratories, as well as the Laboratory of Environmental and Instrumental Chemistry at Universidade Estadual do Oeste do Paraná - Unioeste, Marechal Cândido Rondon, PR, Brazil, for carrying out the chemical analyses.

\section{Contribution of authors:}

Ansilago, M.: Conceptualization, Methodology, Validation, Formal analysis, Investigation, Resources, Data curation, Writing - original draft, Writing - review \& editing, Visualization, Project administration, Funding acquisition. Ottonelli, F.: Conceptualization, Methodology, Validation, Formal analysis, Investigation, Resources, Data curation, Writing - original draft. Carvalho, E.M.: Conceptualization, Methodology, Validation, Formal analysis, Investigation, Resources, Data curation, Writing - original draft, Writing - review \& editing, Visualization, Supervision, Project administration. 


\section{References}

Abdelaziz, A.E.M.; Leite, G.B.; Belhaj, M.A.; Hallenbeck, P.C., 2014. Screening microalgae native to Quebec for wastewater treatment and biodiesel production. Bioresource Technology, v. 157, 140-148. https://doi.org/10.1016/j. biortech.2014.01.114

Ammar, S.H.; Khadim, H.J.; Mohamed, A.I., 2018. Cultivation of Nannochloropsis oculata and Isochrysis galbana microalgae in produced water for bioremediation and biomass production. Environmental Technology Innovation, v. 10, 132-142. https://doi.org/10.1016/j.eti.2018.02.002.

Ansilago, M.; Ottonelli, F.; Carvalho, E.M., 2016. Cultivo da microalga Pseudokirchneriella subcapitata em escala de bancada utilizando meio contaminado com metais pesados. Engenharia Sanitária e Ambiental, v. 21, (3), 603-608. http://dx.doi.org/10.1590/S1413-41522016124295.

Brasil. 2005. Conselho Nacional do Meio Ambiente. Resolução n ${ }^{\circ}$ 375, de 17 de março de 2005. Brasília, Diário Oficial da União, Seção 1, p. 58-63.

Carvalho, E.M.; Ottonelli, F.; Ansilago, M.; Godoy, H.C.; Nakagaki, J.M.; Ramires, I., 2012. Growth kinetics of the microalga Pseudokirchneriella subcapitata (Korshikov) Hindak (Chlorophyceae) in natural water enriched with NPK fertilizer. Biochemical and. Biotechnology Reports, v. 1, (2), 14-18. http://dx.doi.org/10.5433/2316-5200.2012v1n2p14.

Chu, S.P., 1942. The influence of mineral composition of the medium of the growth of the planktonic algae. Journal of Ecology, v. 30, 284-325.

Cossich, E.S., 2000. Biossorção de cromo (III) pela biomassa de alga marinha Sargassum sp. 139 f. Thesis, Doctoring in Chemical Engineering, Faculdade de Engenharia Química, Universidade Estadual de Campinas, Campinas.

Escapa, C.; Coimbra, R.N.; Paniagua, S.; García A.I.; Otero M., 2017. Paracetamol and salicylic acid removal from contaminated water by microalgae. Journal of Environmental Management, v. 203, part 2, 799-806. https://doi.org/10.1016/j.jenvman.2016.06.051.

Gao, C.; Champhelaere, K.A.C., Smolders, E., 2016. Zinc toxicity to the alga Pseudokirchneriella subcapitata decreases under phosphate limiting growth conditions. Aquatic Toxicology, v. 173, 74-82. https://doi.org/10.1016/j. aquatox.2016.01.010.

Gardner, R.; Peters, P.; Peyton, B.; Cooksey, K.E., 2011. Medium pH and nitrate concentration effects on accumulation of triacylglycerol in two members of the chlorophyta. Journal of Applied Phycology, v. 23, (6), 1005-1016. https://doi. org/10.1007/s10811-010-9633-4.

Gonçalves, A.L.; Rodrigues, C.M.; Pires, J.C.M.; Simões, M., 2016. The effect of increasing $\mathrm{CO}_{2}$ concentrations on its capture, biomass production and wastewater bioremediation by microalgae and cyanobacteria. Algal Research, v. 14, 127-136. https://doi.org/10.1016/j. algal.2016.01.008.

González, R.; Garcia-Balboa, C.; Rouco, M.; Lopez-Rodas, V.; Costas, E., 2012. Adaptation of microalgae to lindane: A new approach for bioremediation. Aquatic Toxicology, v. 109, 25-32. https://doi.org/10.1016/j. aquatox.2011.11.015.

Gouveia, L.; Graça, S.; Sousa, C.; Ambrosano, L.; Ribeiro, B.; Botrel, E.P.; Castro Neto, P.; Ferreira, A.F.; Silva, C.M., 2016. Microalgae biomass production using wastewater: Treatment and costs: Scale-up considerations. Algal Research, v. 16, 167-176. https://doi.org/10.1016/j.algal.2016.03.010.

Granados, Y.P.; Ronco, A.; Báez, M.C.D., 2008. Ensayo de toxicidad crónica con el alga Selenastrum capricornutum (Pseudokirchneriella subcapitata) por el método de enumeración celular basado en el uso de hemocitómetro Neubauer. In: Romero, P.R.; Cantú, A.M. Ensayos toxicológicos para la evaluación de sustancias químicas en agua y suelo: La experiencia en México.
Instituto Nacional de Ecología, Secretaría de Medio Ambiente y Recursos Naturales, Mexico, pp. 69-87.

Leong, W.H.; Lim, J.W.; Lam, M.K.; Uemura, Y.; Ho, C.D.; Ho, Y.C., 2018. Co-cultivation of activated sludge and microalgae for the simultaneous enhancements of nitrogen-rich wastewater bioremediation and lipid production. Journal of the Taiwan Institute of Chemical Engineers, v. 87, 216224. https://doi.org/10.1016/j.jtice.2018.03.038.

Lima, P.C.G., 2010. Estudos dos mecanismos de detoxificação e tolerância aos metais cromo e cobre em Pseudokirchneriella subcapitata e Pistia stratiotes e o uso das macrófitas Tpha sp e Phragmites sp na remoção de nutrientes em wetlands construídos. Thesis, Doctoring in Sciences of Environmental Engineering, Escola de Engenharia de São Carlos, Universidade de São Paulo, São Carlos.

Mahapatra, D.M.; Chanakya, H.N.; Ramachandra, T.V., 2014. Bioremediation and lipid synthesis through mixotrophic algal consortia in municipal wastewater. Bioresource Technology, v. 168, 142-150. https://doi.org/10.1016/j. biortech.2014.03.130.

Mantovani, J.R.; Cruz, M.C.P.; Ferreira, M.E.; Barbosa, J.C., 2005. Comparação de procedimentos de quantificação de nitrato. Pesquisa Agropecuária Brasileira, v. 40, (1), 53-59. http://dx.doi.org/10.1590/S0100204X2005000100008.

Mohammadi, M.; Mowla, D.; Esmaeilzadeh, F.; Ghasemi, Y., 2018. Cultivation of microalgae in a power plant wastewater for sulfate removal and biomass production: A batch study. Journal of Environmental Chemical Engineering v. 6, (2), 2812-2820. https://doi.org/10.1016/j.jece.2018.04.037.

Mota, F.S.B.; Von Sperling, M. (Eds.)., 2009. Nutrientes de Esgoto Sanitário: utilização e remoção. ABES, Rio de Janeiro, 428 pp.

Mozeto, A.A.; Zagatto, P.A., 2008. Introdução de Agentes Químicos no Ambiente. In: Zagatto, P.A.; Bertoletti, E. (Eds.). Ecotoxicologia Aquática: Princípios e Aplicações. Rima, São Paulo, pp. 15-38.

Pavan, M.A.; Bloch, M.F.; Zempulski, H.C.; Miyazawa, M.; Zocoler, D.C., 1992. Manual de análises químicas de solo e controle de qualidade. 2. ed. IAPAR, Londrina, v. 40.

Peng, Y.; Deng, A.; Gong, X.; Li, X.; Zhang, Y., 2017. Coupling process study of lipid production and mercury bioremediation by biomimetic mineralized microalgae. Bioresource Technology, v. 243, 628-633. https://doi.org/10.1016/j. biortech.2017.06.165.

Priyadarshani, I.; Rath, B., 2012. Commercial and industrial applications of microalgae - A review. Journal of Algal Biomass Utilization, v. 3, (4), 89-100.

Ramachandra, T.V.; Madhab, M.D.; Shilpi, S.; Joshi, N.V., 2013. Algal biofuel from urban wastewater in India: Scope and challenges. Renewable \& Sustainable Energy Reviews, v. 21, 767-777. https://doi.org/10.1016/j.rser.2012.12.029.

Redfield, A.C., 1958. The biological control of chemical factors in the environment. American Scientist, v. 46, (3), 205-221.

Ridley, C.J.A.; Parker, B.M.; Norman, L.; Schlarb-Ridley, B.; Dennis, R.; Jamieson, A.E.; Clark, D.; Skill, S.C.; Smith, A.G.; Davey, M.P., 2018. Growth of microalgae using nitrate-rich brine wash from the water industry. Algal Research, v. 33, 91-98. https://doi.org/10.1016/j.algal.2018.04.018.

Saavedra, R.; Muñoz, R.; Taboada, M.E.; Vega, M.; Bolado, S., 2018. Comparative uptake study of arsenic, boron, copper, manganese and zinc from water by different green microalgae. Bioresource Technology, v. 263, 49-57. http://doi.org/10.1016/j.biortech.2018.04.101.

Sathasivam, R.; Radhakrishnan, R.; Hashem, A.; Allah, E.F.A., 2019. Microalgae metabolites: A rich source for food and medicine. Saudi Journal of Biological Sciences, v. 26, (4), 709-722. https://doi.org/10.1016/j.sjbs.2017.11.003. 
Schmitz, R.; Magro, C.E.; Colla, L.M., 2012. Aplicações ambientais de microalgas. Revista CIATEC-UPF, v. 4, (1), 48-60. https://doi.org/10.5335/ciatec.v4i1.2393.

Shen, Y.; Zhu, W.; Li, H.; Ho, S.F.; Chen, J.; Xie, Y.; Shi, X., 2018. Enhancing cadmium bioremediation by a complex of water-hyacinth derived pellets immobilized with Chlorella sp. Bioresource Technology, v. 257, 157-163. https://doi.org/10.1016/j.biortech.2018.02.060.

Silva, K.M.D.; Rezende, L.C.S.H.; Silva, C.A.; Bergamasco, R.; Gonçalves, D.S., 2013. Caracterização físico-química da fibra de coco verde para a adsorção de metais pesados em efluente de indústria de tinta. Engevista, v. 15, (1). https:// doi.org/10.22409/engevista.v15i1.387

Sipaúba-Tavares, L.H.; Ibarra, L.C.C.; Fioresi, T.B., 2009. Cultivo de Ankistrodesmus gracilis (reisch) korsikov (Chlorophyta) em laboratório utilizando meio chu12 e de macrófita com npk. Boletim do Instituto de Pesca, v. $35,(1), 111-118$

Sipaúba-Tavares, L.H.; Rocha, O., 1993. Cultivo em larga escala de organismos planctônicos para alimentação de larvas e alevinos de peixes: I - algas clorofíceas. Biotemas, v. 6, (1), 93-106. https://doi.org/10.5007/\%25x

Soares, C.R.F.S.; Accioly, A.M.A.; Marques, T.C.L.L.S.M.; Siqueira, J.O.; Moreira, F.M.S., 2001. Acúmulo e distribuição de metais pesados nas raízes, caule e folhas de mudas de árvores em solo contaminado por rejeitos de indústria de zinco. Revista Brasileira de Fisiologia Vegetal, v. 13, (3), 302-315. http://dx.doi.org/10.1590/S0103-31312001000300006.
Sousa, C.A.; Soares, H.M.V.M.; Soares, E.V., 2018. Toxic effects of nickel oxide $(\mathrm{NiO})$ nanoparticles on the freshwater algae Pseudokirchneriella subcapitata. Aquatic Toxicology, v. 204, 80-90. https://doi.org/10.1016/j. aquatox.2018.08.022.

Sperling, E.V., 2001. Uso de relações limnológicas para avaliação da qualidade da água em mananciais de abastecimento. In: Associação Brasileira de Engenharia Sanitária e Ambiental; AIDIS. Saneamento ambiental: desafio para o século Rio de Janeiro. Anais... Ed. ABES, Rio de Janeiro, v.4, pp. 1-3.

Tedesco, M.J.; Gianello, C.; Bissani, C.A.; Bohnen, H.; Volkweiss, S.J., 1995. Análises de solo, plantas e outros materiais. Universidade Federal do Rio Grande do Sul, Faculdade de Agronomia, Porto Alegre (Boletim Técnico de Solos, 5).

Wang, M.; Kuo-Dahab, W.C.; Dolan, S.; Park, C., 2014. Kinetics of nutrient removal and expression of extracellular polymeric substances of the microalgae, Chlorella sp. and Micractinium sp., in wastewater treatment. Bioresource Technology, v. 154, 131-137. https://doi.org/10.1016/j. biortech.2013.12.047.

Welz, B.; Sperling, M., 1999. Atomic absorption spectrometry. $3^{\text {rd }}$ ed. $\mathrm{VCH}$, Weinheim.

Zhang, X.; Zhao, X.; Wan, C.; Chen, B.; Bai, F., 2016. Efficient biosorption of cadmium by the self-flocculating microalga Scenedesmus obliquus AS-6-1. Algal Research, v. 16, 427-433. https://doi.org/10.1016/j.algal.2016.04.002. 